\title{
Movement patterns of the round stingray Urobatis halleri (Cooper) near a thermal outfall
}

\author{
J. J. VAudo* AND C. G. Lowe† \\ Department of Biological Sciences, California State University Long Beach, Long \\ Beach, CA 90840, U.S.A.
}

(Received 3 January 2005, Accepted 12 December 2005)

\begin{abstract}
Fine-scale movements and site fidelity of round stingrays Urobatis halleri at Seal Beach California, U.S.A., were examined using acoustic telemetry. Actively tracked fish generally exhibited limited nearshore movement, with greater distances travelled at night when the tide was ebbing than during the day with ebbing tides. Increases in round stingray activity were associated with increases in ambient temperature. Passively tracked fish showed seasonal patterns in their presence at Seal Beach. Males left Seal Beach during the autumn, returned the following spring, and remained in the area until the following autumn. Females spent far less time at Seal Beach, remaining in the area for a few weeks during June and July. Passively tracked round stingrays were recorded more often in the warm waters of the San Gabriel River mouth (the location of a thermal outfall from an electric-generating station) than adjacent beaches, with fish often returning to Seal Beach after periods of absence. Anthropogenic effects resulting from coastal development may have created environmental conditions (i.e. warmer water and finer sediments) that influence the movements and site fidelity of round stingrays.

(C) 2006 The Fisheries Society of the British Isles
\end{abstract}

Key words: behaviour; elasmobranch; telemetry; temperature.

\section{INTRODUCTION}

Water temperature has been shown to influence the distribution, abundance and movement patterns of marine ectothermic fishes, including many elasmobranchs (Snelson \& Williams, 1981; Matern et al., 2000; Hopkins \& Cech, 2003). The effects of water temperature on behaviour and ecology vary across species depending largely on their physiology. Some species and populations may be more thermally tolerant than others, thereby allowing them access to habitats inaccessible to potential competitors or predators (Fangue \& Bennett, 2003). Other species of elasmobranchs, e.g. blue sharks Prionace glauca (L.), bat rays Myliobatis californica Gill and juvenile scalloped hammerhead sharks Sphyrna

$\dagger$ Author to whom correspondence should be addressed. Tel.: +1 562985 4918; fax: +1 562985 8878; email: clowe@csulb.edu

*Present address: Department of Biological Sciences, Florida International University, Miami, FL 33199, U.S.A. 
lewini (Griffith \& Smith) are thought to utilize thermal gradients to optimize energetic gain (Carey \& Scharold, 1990; Matern et al., 2000; Lowe, 2002). In addition, large-scale oceanographic regimes (e.g. ENSO events) can dramatically shift populations, temporally expanding or contracting a species' geographical range.

Coastal development and urbanization have been shown to dramatically change the thermal characteristics of coastal environments. Many coastal electric-generating stations use sea water as a coolant and discharge heated sea water into nearshore areas. Although there have been numerous studies documenting the effects of these heated sea water outfalls on a variety of marine organisms (Magnuson et al., 1979; Langford, 1983, 1990; Bamber, 1995), few studies have examined how these outfalls influence the distribution and movements of elasmobranchs (Hoisington \& Lowe, 2005).

Several electric-generating stations discharge heated sea water into the lower reaches of the San Gabriel River, which empties at Seal Beach, California, U.S.A. Seal Beach is known for its population of round stingrays Urobatis halleri (Cooper), a small (c. $56 \mathrm{~cm}$ total length, $L_{\mathrm{T}}$ ) subtropical species ranging from Panama to Eureka, California, although round stingrays are rare north of the Southern California Bight (Roedel, 1953). Babel (1967) and Hoisington \& Lowe (2005) documented higher densities of round stingrays at Seal Beach than adjacent beaches and have suggested that the fish may prefer the warmer water at Seal Beach.

Previous tag and recapture studies of round stingrays at Seal Beach have indicated that the fish seasonally aggregate near the San Gabriel River mouth, but may not remain there for periods of more than several weeks (Babel, 1967). Of 2183 round stingrays, tagged while sampling biweekly only at Seal Beach, a total of 13 fish $(0 \cdot 6 \%)$ was recaptured within $1 \mathrm{~km}$ of Seal Beach (C. G. Lowe, unpubl. data). Despite the higher density and abundance of round stingrays at Seal Beach, which may be attributed to elevated water temperatures (Hoisington \& Lowe, 2005), it is unclear how long the fish remain at Seal Beach (i.e. in warmer water), how changes in water temperature may affect their fine-scale movements and whether they show any seasonal fidelity to the area. Therefore, the primary objectives were to: 1) assess the short-term, fine-scale movement patterns of round stingrays caught near the San Gabriel River mouth at Seal Beach and 2) determine whether round stingrays show any site fidelity to Seal Beach.

\section{MATERIALS AND METHODS}

\section{STUDY SITE}

Seal Beach, $\left(33^{\circ} 44^{\prime} \mathrm{N} ; 118^{\circ} 07^{\prime} \mathrm{W}\right)$ is a small $(1.6 \mathrm{~km})$ south facing, sandy beach, which is bordered to the east and west by jetties that protect Alamitos and Anaheim Bays (Fig. 1). The San Gabriel River, a seasonal stream typical of southern California, has been modified over the last 50 years to function as a flood control channel and only periodically discharges freshwater runoff following storm events. Two electric-generating stations located $2 \mathrm{~km}$ from the mouth of the San Gabriel River use seawater as coolant and discharge warmed sea water into the river, resulting in elevated seawater temperatures at Seal Beach (Reish, 1956). 


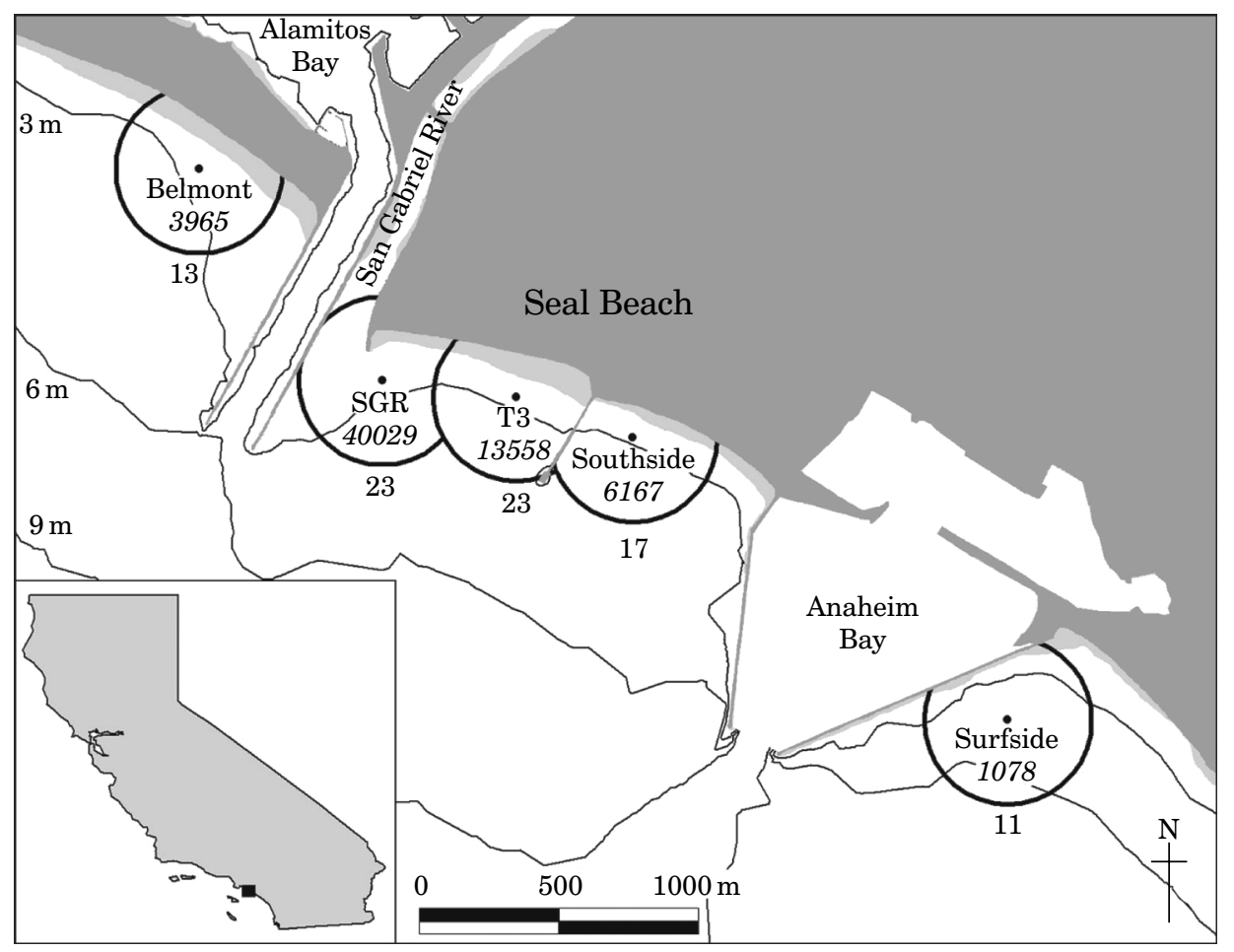

FIG. 1. Bathymetric map of Seal Beach, California, U.S.A indicating the locations and designations of automated acoustic receivers $(\mathbf{O})$. Total number of detections at each automated acoustic receiver for acoustically monitored round stingrays from 13 September 2002 to 5 July 2004. The numbers within the rings are the total number of detections recorded at a given automated acoustic receiver and the number of fish detected at a given acoustic receiver is located below each ring. Land $(\square)$, intertidal sand $(\square)$. $\square$, on inset map shows the location of Seal Beach in California.

\section{FINE-SCALE MOVEMENTS}

Active acoustic telemetry tracking was used to assess the short-term, fine-scale movements of the round stingray at Seal Beach. Adult round stingrays were captured using a $30 \mathrm{~m}$ beach seine or hand-held dip-net, and held in small pools of water until tagging. Fish were measured, sexed and a $1.3 \mathrm{~cm}$ Peterson disc tag was fitted to the proximal margin of the pectoral fin. An acoustic transmitter (V8SC-6L, $9 \mathrm{~mm}$ diameter $\times 20 \mathrm{~mm}$, frequencies: $67 \cdot 3-75 \cdot 0 \mathrm{kHz}$, continuous pulse rate $1000-2000 \mathrm{~ms}$, Vemco Ltd, Shad Bay, Nova Scotia, Canada) was then attached to the top of the Peterson disk with a corrosible wire (Cartamil et al., 2003). Transmitter mass in air did not exceed $1.5 \%$ of a round stingray's body mass. The handling of fish for measurement and tag attachment did not exceed 3 min. Fish were returned to the pools and monitored for several minutes before release at the location of capture. No fish showed negative effects from tagging, and all round stingrays swam away strongly upon release in a manner similar to that of untagged fish.

Directly after release, round stingrays were continuously tracked for periods up to $72 \mathrm{~h}$ from a 5 m skiff fitted with a hull-mounted, directional hydrophone (VH10, Vemco Ltd) connected to an acoustic receiver (VR60, Vemco Ltd) as described in Holland et al. (1992). Because of the benthic and cryptic behaviour of round stingrays, 'trackers' were able to position the skiff within $5 \mathrm{~m}$ of a round stingray without eliciting a flight response. The round stingrays' geographical locations were determined every $15 \mathrm{~min}$, and latitude and longitude were taken using a hand-held GPS (Magellan GPS 315, 
accuracy: $4 \mathrm{~m}$ ). Once a track was completed, searches were conducted for the tagged round stingrays, as time allowed, over the 28 day battery life of the transmitter. Searches typically focused on the areas of Seal Beach, Belmont Shore and Surfside, but also included Alamitos and Anaheim Bays (Fig. 1).

The recorded positions of each tracked round stingray were plotted on a bathymetric chart of the Seal Beach area using ArcView GIS 3.2a and the distances between successive positions were determined using the Animal Movement Analyst Extension for ArcView (Hooge \& Eichenlaub, 2000). These rates of movement were divided into periods of daytime and night-time based on the times of sunrise and sunset and further divided into periods of ebbing and flooding tides based on times of high and low tide. Rates of movement were then $\log _{10}$ transformed to meet convergence criteria. Logged data were analysed using a mixed model ANOVA in SAS v. 8 with sex (male or female), time of day (daytime or night-time) and tidal direction (ebbing or flooding) as fixed factors and each round stingray as a repeated random factor nested within each sex.

Continuous seafloor water temperatures were recorded at Seal Beach, Surfside and Belmont Shore during the final five fish tracks. For these five fish, rates of movement and water temperature were examined over $2 \mathrm{~h}$ intervals. Each interval was compared to the previous interval to determine if round stingray movement and water temperature had increased or decreased. The frequency of occurrence of these events was recorded and a $\chi^{2}$ test of independence was performed to determine if increases in temperature were associated with increased fish movement.

\section{SEASONAL FIDELITY}

Acoustic monitoring was used to determine the seasonal fidelity of individual round stingrays to the Seal Beach area. Five automated omni-directional acoustic receivers (VR2, Vemco Ltd) were mounted to sand anchors $c .0 .5 \mathrm{~m}$ above the seafloor in the waters off three Seal Beach sites, and the two neighbouring beaches of Surfside and Belmont Shore (Fig. 1). Automated acoustic receivers were located within $60 \mathrm{~m}$ of the shoreline in $c$. $2-3 \mathrm{~m}$ of water. Automated acoustic receivers continuously listened for and recorded the transmitter identity number, date and time when a signal was detected from a coded acoustic transmitter (Coded V8SC-6L, $9 \mathrm{~mm}$ diameter $\times 20 \mathrm{~mm}$, frequency $69.0 \mathrm{kHz}$, estimated battery life c. 8 months, Vemco Ltd). Each transmitter emitted a unique coded signal at random time intervals, ranging from 60 to $180 \mathrm{~s}$ in duration. Seafloor water temperatures at each location were continuously measured using StowAway TidbiT temperature loggers (Onset Computer) attached to each acoustic receiver.

All round stingrays acoustically monitored were captured at Seal Beach between September 2002 and June 2003 using a $30 \mathrm{~m}$ beach seine. Fish were measured and tagged with coded acoustic transmitters using the same procedures as described above, and released at the site of capture.

To determine whether water temperature influenced round stingray seasonal site fidelity, a Friedman test was performed comparing the numbers of fish detected at automated acoustic receivers at warm sites with the number of fish detected at cooler sites using month as a blocking factor. Sites were ranked each month according to their maximum water temperature. This analysis was also run using the total number of detections for all round stingrays at each automated acoustic receiver at warm sites with the total number of detections for all fish at cooler sites, using month as a blocking factor.

\section{RESULTS}

\section{FINE-SCALE MOVEMENTS}

Ten adult round stingrays (disc widths: 192-285 $\mathrm{mm}$ ) were actively tracked continuously for periods of 5·25-72.0 h during the summer and autumn between 
October 2000 and August 2003. One round stingray was relocated 18 days after its original track and was tracked for two consecutive daytime periods, bringing its total number of hours tracked to $90 \cdot 5 \mathrm{~h}$. Four of the tracked round stingrays were relocated a total of nine times after the conclusion of their initial tracks and two fish were relocated over 1 week after their initial track (Fig. 2). The longest period of time between the conclusion of a round stingray's track and its relocation was 19 days.

Tracked round stingrays generally remained in waters $2 \cdot 5-3 \cdot 5 \mathrm{~m}$ deep, but often moved into shallower water, remaining 20-30 m offshore of the surf zone and exhibited little movement interspersed with periods of no discernable movement (Fig. 2). Periods of inactivity typically lasted 2-4 h. Based on observations of captive and non-captive round stingrays, fish spent much of their time immobile, buried within the substratum, and it is likely that tracked fish did the same, however, small movements were not detectable with the tracking methodology used.

Round stingrays showed movements related to a combination of tidal and diel periodicities (mixed model ANOVA, $F_{1,8}, P=0 \cdot 04$ ). Fish exhibited their highest rates of movement at night when the tide was ebbing. This rate was significantly

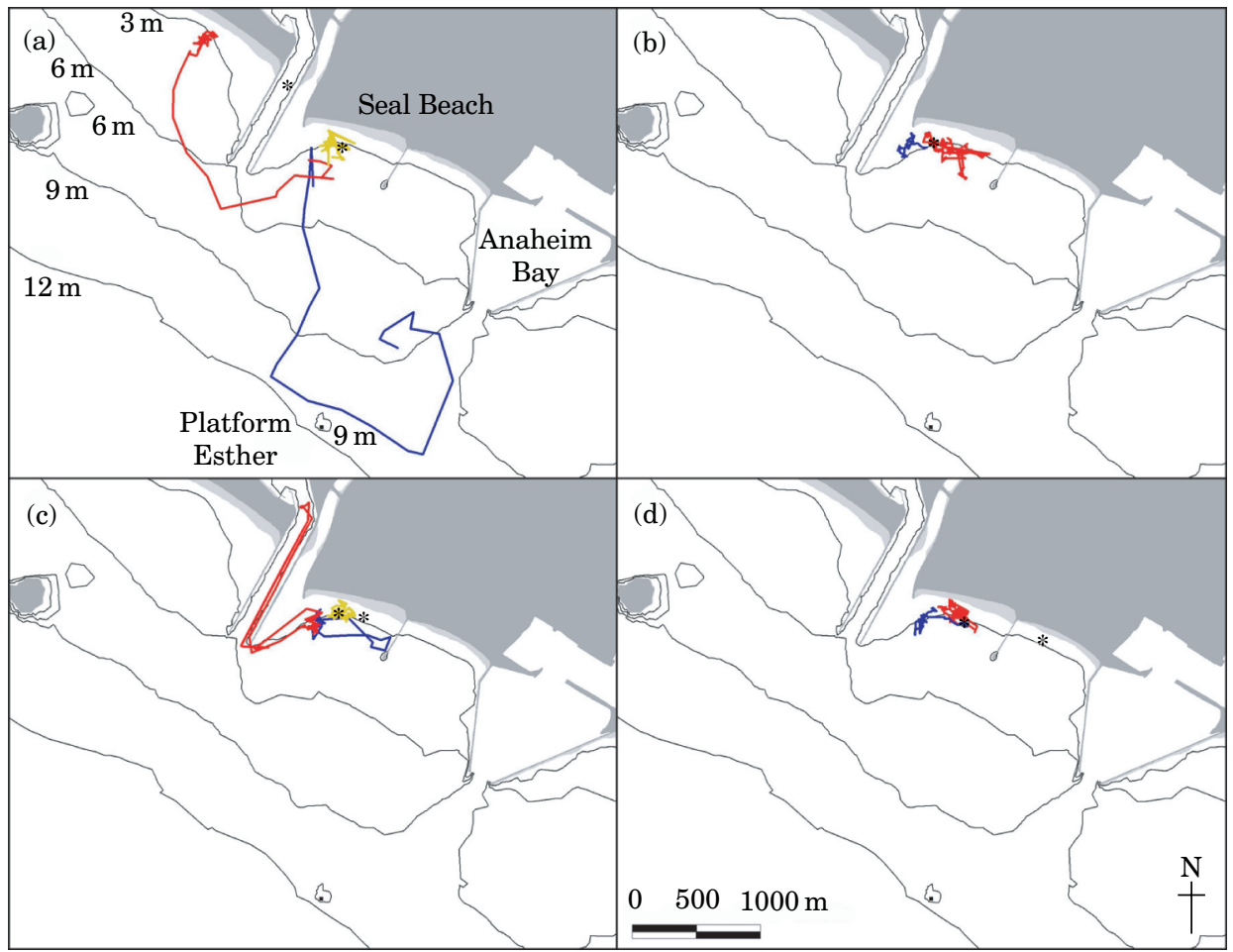

FIG. 2. Active tracks of 10 round stingrays plotted on a bathymetric map of Seal Beach, California, U.S.A. Each coloured line represents a single track. Durations of each track were: (a) $48 \mathrm{~h}$ (red), $5 \mathrm{~h}$ (blue) and $50 \mathrm{~h}$ (yellow), (*, relocation of yellow), (b) $14 \mathrm{~h}$ (blue) and $56 \mathrm{~h}$ (red), (*, relocation of red), (c) $16 \mathrm{~h}$ (blue), $50 \mathrm{~h}$ (yellow) and $50 \mathrm{~h}$ (red), (*, relocation of red) and (d) $33 \mathrm{~h}$ (blue), and $90 \mathrm{~h}$ (red), (*, relocation of red). Land ( $\square$ ), and intertidal sand $(\square)$ is indicated. 


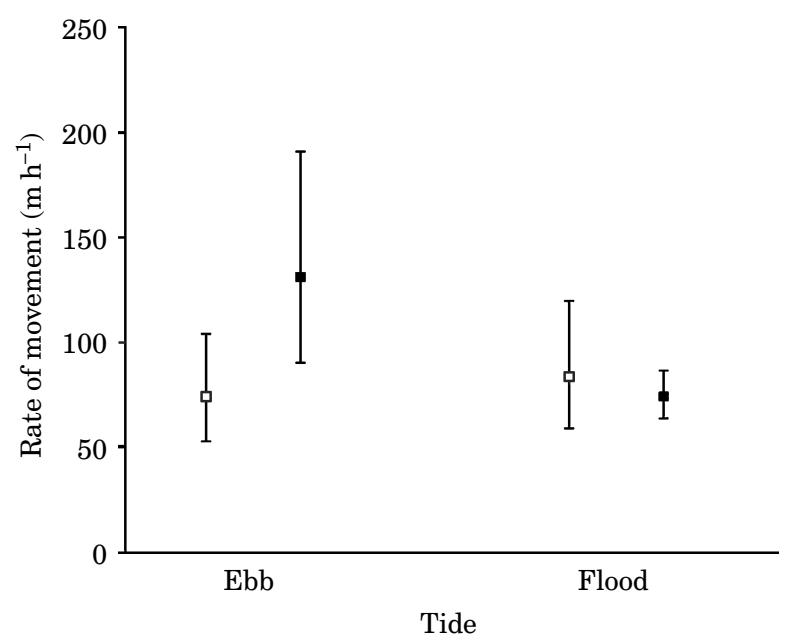

FIG. 3. Mean \pm S.E. rate of movement of round stingrays actively tracked at Seal Beach during the day $(\square)$ and night ( ) and during ebbing and flooding tides.

higher than the round stingrays' movement rate during daytime when the tide was ebbing (Tukey's test, d.f. $=8, P=0.03$ ), but did not significantly differ from rates of movement during the daytime when tides were flooding (Tukey's test, d.f. $=8, P=0.25$ ) or at night when tides were flooding (Tukey's test, d.f. $=8, P=0 \cdot 13$ ) (Fig. 3). In addition, increases in round stingray movements had a positive association with increases in water temperature (coefficient of association $=0 \cdot 21, \chi^{2}$ test of independence, d.f. $\left.=1, P=0 \cdot 019\right)$.

\section{SEASONAL FIDELITY}

Twenty-five adult round stingrays (disc widths: 179-275 mm) were acoustically monitored between September 2002 and June 2004. Both males and females exhibited seasonal movements to and from Seal Beach.

Tagged male round stingrays were most often detected in the summer and early autumn and the number of tagged male fish in the area dropped sharply in November 2002, with only three males detected during the winter. The following spring, the males returned to Seal Beach. Only three of the original 10 males did not return during the following spring, and during the summer, $c$. 1 year after tagging, six of the original 10 male round stingrays were detected (Fig. 4). The number of males in the area decreased again in November, and by December, only two of the males were detected.

Female round stingrays were caught less frequently than males during seining and only four had been tagged during autumn 2002. Three of these females were detected during January and two were detected during March 2003 (Fig. 4). Two of these females returned briefly during the summer of 2003 and one was even detected throughout the autumn and winter. Nine additional females were tagged in June 2003. Many of these females left the area within weeks of being tagged and only two of these round stingrays were detected after July (Fig. 4). 


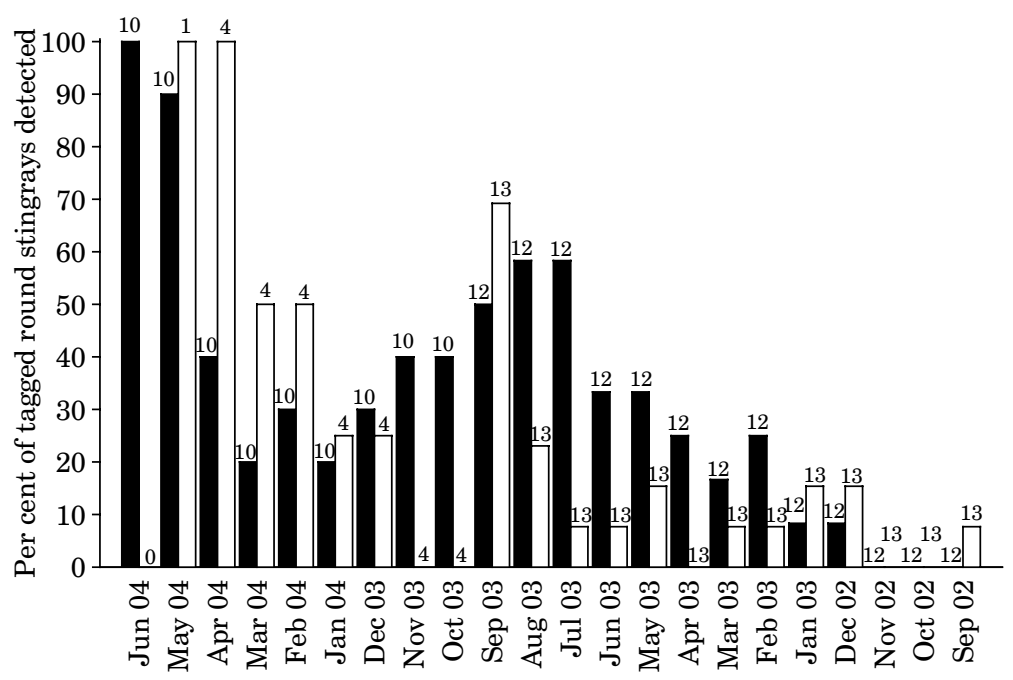

Fig. 4. Per cent of tagged male $(\boldsymbol{\square})$ and female $(\square)$ round stingrays detected at the three Seal Beach automated acoustic receivers each month. The number above each bar represents the number of fish at liberty during a given month.

One female tagged in June was captured and released from a gillnet in upper Newport Bay in August, $>30 \mathrm{~km}$ south of Seal Beach. This round stingray was detected at Surfside $<1$ month after its recapture in Newport Bay and was later detected at Seal Beach 1 year after being originally tagged.

Seafloor water temperatures varied substantially at all five acoustic receiver locations over the duration of the study. Seal Beach sites tended to have the highest temperatures with temperatures usually increasing with proximity to the San Gabriel River mouth. All Seal Beach sites exceeded $26^{\circ} \mathrm{C}$ during summer and autumn months, whereas none of the adjacent beach sites exceeded $26^{\circ} \mathrm{C}$. All sites also experienced tidal fluctuations in temperature, with temperatures increasing during ebbing tides and decreasing during flooding tides. These fluctuations often resulted in temperature changes of $5-10^{\circ} \mathrm{C}$ at Seal Beach sites, but usually varied only $2-3^{\circ} \mathrm{C}$ at non Seal Beach sites.

Overall, most round stingray activity was concentrated near the San Gabriel River mouth, which tends to be the warmest site, with a considerable amount of activity at the other two Seal Beach sites (Fig. 1). During a given month, more round stingrays were detected at automated acoustic receivers located in the warmest waters of the study site (Friedman test, d.f. $=4, \quad P<0 \cdot 001$ ). Automated acoustic receiver locations with the highest maximum seafloor water temperatures were visited by more round stingrays than the locations with the two lowest maximum temperatures (Friedman test post hoc comparisons, d.f. $=4, P<0 \cdot 003$ ). Based on number of detections, fish also spent more time in the warmest waters (Friedman test, d.f. $=4, P=0 \cdot 001$ ). Higher numbers of detections were recorded at locations with the highest maximum temperature than at the locations with the two lowest maximum temperatures (Friedman test post hoc comparisons, d.f. $=4, P<0.003$ ). The locations with 
the second and third highest maximum seafloor water temperatures also had significantly more detections than the location with the lowest maximum water temperature (Friedman test post hoc comparisons, d.f. $=4, P<0 \cdot 003$ ).

\section{DISCUSSION}

Round stingrays displayed limited short-term movements, punctuated by periods of little to no activity. Increases in round stingray activity were associated with increases in seafloor water temperature and fish exhibited significantly higher rates of movement at night when the tide was ebbing. During ebbing tides water temperatures at Seal Beach can increase by as much as $10^{\circ} \mathrm{C}$. Temperature changes of this magnitude over a relatively short period of time could have a substantial effect on metabolic rates. Bat rays, for example, are extremely sensitive to temperature changes between $14^{\circ}$ and $20^{\circ} \mathrm{C}\left(Q_{10}=6 \cdot 81\right)$ (Hopkins \& Cech, 1994) and it has been hypothesized that they exhibit behavioural thermoregulatory movements to take advantage of varying water temperatures (Matern et al., 2000). The $Q_{10}$ of round stingrays has not been reported, but even if round stingrays have a more typical, lower temperature sensitivity over the same temperature range, such as bull rays Myliobatis aquila (L.) $\left(Q_{10}=1 \cdot 87\right.$; Du Preez et al., 1988) or leopard sharks Triakis semifasciata Girard $\left(Q_{10}=2 \cdot 50\right.$; Miklos et al., 2003), a change in metabolic rate of this magnitude may still influence behavioural patterns. Juvenile scalloped hammerhead sharks and Hawaiian stingrays Dasyatis lata (Garman) in Kaneohe Bay both showed increased rates of movement during the summer when water temperatures were elevated (Lowe, 2002; Cartamil et al., 2003). So, it is possible that the dramatic changes in water temperature that occur over tidal cycles at Seal Beach result in the increased rates of movement observed in round stingrays.

Round stingrays may also exhibit diel patterns of activity that may explain higher rates of movement at night at Seal Beach, particularly during ebbing tides. In a preliminary respirometry study, round stingrays were found to be more active and to have higher metabolic rates at night than during the day (T. Price \& C. G. Lowe, unpubl. data). Nocturnal activity has been observed in many benthic elasmobranchs (Nelson \& Johnson, 1970, 1980; Standora \& Nelson, 1977; Holland et al., 1993; Cartamil et al., 2003) and is thought to be related to foraging, antipredatory and mating behaviours. Nevertheless, photoperiod is thought to be the primary cue in regulating nocturnal activity patterns. Although it is unclear as to why round stingrays are more active during periods of elevated water temperature, particularly at night, it is possible that the increased activity during these periods may be to find more desirable environmental conditions, increase foraging success and locate similarly active mates.

Despite displaying limited movements during tracks, round stingrays left Seal Beach within a few weeks, supporting observations from tag and recapture data that round stingrays aggregate at Seal Beach then disperse (C. G. Lowe, unpubl. data). This pattern was also seen in acoustically monitored round stingrays. Furthermore, it is unclear how far round stingrays go when they leave Seal Beach. Despite searching several kilometres of coastline, most actively tracked fish that had left Seal Beach were not relocated within the search areas, 
suggesting round stingrays may move substantial distances from Seal Beach. This is further supported by the record of the one acoustically monitored round stingray that was recaptured in Newport Bay $>30 \mathrm{~km}$ from Seal Beach.

The presence of the round stingray aggregation indicates some feature of Seal Beach is attractive to these fish, but this feature is not enough to keep fish in the area over a period of several weeks. The obvious feature, which sets Seal Beach apart from adjacent beaches, is its elevated water temperature. There is no significant difference in salinity between Seal Beach and Surfside Beach despite the influence of the San Gabriel River (Hoisington, 2004). Prior benthic surveys of Seal Beach have indicated that the area surrounding the San Gabriel River mouth is relatively depauperate of infaunal species (Turner \& Strachan, 1969), on which round stingrays are known to feed (Babel, 1967). Nevertheless, the overall seasonal average water temperature is higher at Seal Beach than any of the other locations studied, and if water temperature was the primary factor influencing aggregation behaviour, then it might be expected that round stingrays would remain at Seal Beach all year around, and yet this was not observed.

Individual round stingrays, however, do return to Seal Beach seasonally. The return and presence of acoustically monitored fish coincided with seasonal peaks in abundance from concurrent beach seining (Hoisington \& Lowe, 2005) and coincided with the round stingray mating season in southern California (Babel, 1967). In addition, round stingrays sexually segregate (Russell, 1955; Babel, 1967; Hoisington \& Lowe, 2005) and acoustically monitored females were almost exclusively detected during the times of seasonal peaks in abundance. The timing of return and high abundance of male and female round stingrays suggests that the presence of round stingrays at Seal Beach may be related to reproduction. Large seasonal mating aggregations of round stingrays have been observed in the Sea of Cortez near Bahia Kino, Mexico under similar environmental conditions (Nordell, 1994).

Even if the timing of round stingrays aggregations at Seal Beach coincides with reproductive behaviour, monitored fish were most often recorded in and returned to the areas of warmest water. Overall, the number of round stingray detections decreased with increasing distance from the San Gabriel River mouth, which is similar to observations of round stingray density and abundance (Hoisington \& Lowe, 2005). These observations suggest that water temperature may play some role in the aggregation of round stingrays at Seal Beach.

Seal Beach receives periodic influx of fresh water and warm seawater effluent from electric-generating stations from the San Gabriel River, which results in widely fluctuating water temperatures with tide at Seal Beach. In addition, neighbouring breakwaters and jetties reduce wave activity and increase the accumulation of fine sediments. These conditions are similar to those of estuaries and shallow protected bays in which round stingrays are known to mate and pup (Babel, 1967; Nordell, 1994). These alterations to the Seal Beach environment may serve as cues to locate mating grounds, thereby attracting round stingrays to this area seasonally.

Urbanization of the southern California coastline has led to the loss of coastal habitat probably used by round stingrays for reproduction. In addition, coastal electric-generating stations have altered the thermal environment of Seal Beach creating conditions that mimic these habitats. As a result, these factors may drive 
round stingray movements on multiple scales as fish at Seal Beach alter their rates of movements with tidal changes in water temperature and appear to be seasonally attracted to the warm waters of Seal Beach as they seek breeding habitat, but shortly thereafter leave, creating seasonal transient aggregations.

We would like to thank everyone who tracked for this project, in particular, G. Moss, G. Hoisington, D. Topping, Y. Papastamatiou, D. Cartamil, B. Ziegler, G. Goodmanlowe and L. Bellquist. We also thank H. Simonds and J. Cobb for information on recaptured rays. We owe a special thanks to R. Pounds and the City of Seal Beach lifeguards for their support and invaluable field assistance. This research was conducted with support from the University of Southern California Sea Grant Program, part of the National Sea Grant College Program, National Oceanic and Atmospheric Administration, U.S. Department of Commerce (grant \# NA86RG0054), by the California State Resources Agency, California State University Long Beach, Long Beach Aquarium of the Pacific, Boeing Corp., American Elasmobranch Society, City of Seal Beach Lifeguards and the Surfrider Foundation. This study was approved by the CSULB Animal Welfare Board (protocol \#175).

\section{References}

Babel, J. S. (1967). Reproduction, life history, and ecology of the round stingray, Urolophus halleri Cooper. Fish Bulletin California Department of Fish and Game 137, 1-104.

Bamber, R. N. (1995). The influence of rising background temperature on the effects of marine thermal effluents. Journal of Thermal Biology 20, 105-120.

Carey, E. G. \& Scharold, J. V. (1990). Movements of blue sharks (Prionace glauca) in depth and course. Marine Biology 106, 329-342.

Cartamil, D. P., Vaudo, J. J., Lowe, C. G., Wetherbee, B. M. \& Holland, K. N. (2003). Diel movement patterns of the Hawaiian stingray, Dasyatis lata: Implications for ecological interactions between sympatric elasmobranch species. Marine Biology 142, 841-847.

Du Preez, H., McLachlan, A. \& Marias, J. (1988). Oxygen consumption of two nearshore elasmobranchs, Rhinobatus annulatus (Muller \& Henle, 1841) and Myliobatis aquila (Linnaeus, 1758). Comparative Biochemistry and Physiology A 89, 283-294.

Fangue, N. A. \& Bennett, W. A. (2003). Thermal tolerance responses of laboratoryacclimated and seasonally acclimatized Atlantic stingray, Dasyatis sabina. Copeia 2003, 315-325.

Hoisington, G., IV (2004). Distribution, abundance, and population structure of the round stingray (Urobatis halleri) near a thermal discharge at Seal Beach, California. Master's Thesis, California State University, Long Beach, CA.

Hoisington, G., IV \& Lowe, C. G. (2005). Abundance and distribution of round stingray, Urobatis halleri, near a thermal outfall. Marine Environmental Research 60, 437-453.

Holland, K., Lowe, C., Peterson, J. \& Gill, A. (1992). Tracking coastal sharks with small boats: hammerhead shark pups as a case study. Australian Journal of Marine and Freshwater Research 43, 61-66.

Holland, K. N., Wetherbee, B. M., Peterson, J. D. \& Lowe, C. G. (1993). Movements and distribution of hammerhead shark pups on their natal grounds. Copeia 1993, 495-502.

Hooge, P. \& Eichenlaub, W. (2000). Animal Movements Extension to ArcView. Anchorage, AK: Alaska Biological Center, US Geological Survey.

Hopkins, T. E. \& Cech, J. J., Jr (1994). Effect of temperature on oxygen consumption of the bat ray, Myliobatis californica (Chondrichthyes, Myliobatidae). Copeia 1994, 529-532. 
Hopkins, T. E. \& Cech, J. J., Jr (2003). The influence of environmental variables on the distribution and abundance of three elasmobranchs in Tomales Bay, California. Environmental Biology of Fishes 66, 279-291.

Langford, T. E. (1983). Electricity Generation and the Ecology of Natural Waters. Liverpool: Liverpool University Press.

Langford, T. E. (1990). Ecological Effects of Thermal Discharges. New York: Elsevier.

Lowe, C. G. (2002). Bioenergetics of free-ranging juvenile scalloped hammerhead sharks (Sphyrna lewini) in Kane'ohe Bay, O'ahu, HI. Journal of Experimental Marine Biology and Ecology 278, 141-156.

Magnuson, J. J., Crowder, L. B. \& Medvick, P. A. (1979). Temperature as an ecological resource. American Zoologist 19, 331-343.

Matern, S. A., Cech, J. J., Jr \& Hopkins, T. E. (2000). Diel movements of bat rays, Myliobatis californica, in Tomales Bay, California: Evidence for behavioral thermoregulation? Environmental Biology of Fishes 58, 173-182.

Miklos, P., Katzman, S. M. \& Cech, J. J., Jr (2003). Effect of temperature on oxygen consumption of the leopard shark, Triakis semifasciata. Environmental Biology of Fishes 66, 15-18.

Nelson, D. \& Johnson, R. (1970). Diel activity rhythms in the nocturnal, bottom-dwelling sharks, Heterodontus francisci and Cephaloscyllium ventriosum. Copeia 1970, 732-739.

Nelson, D. \& Johnson, R. (1980). Behavior of the reef sharks of Rangiroa, French Polynesia. National Geographic Society Research Reports 12, 479-499.

Nordell, S. E. (1994). Observations of the mating behavior and dentition of the round stingray, Urolophus halleri. Environmental Biology of Fishes 39, 219-229.

Reish, D. J. (1956). An ecological study of lower San Gabriel River, California, with special reference to pollution. California Fish and Game 42, 51-62.

Roedel, P. (1953). Common ocean fishes of the California coast. Fish Bulletin California Department of Fish and Game 91, 1-188.

Russell, F. (1955). Multiple caudal spines in the round stingray, Urobatis halleri. California Fish and Game 41, 213-217.

Snelson, F. F., Jr \& Williams, S. E. (1981). Notes on the occurrence, distribution, and biology of elasmobranch fishes in the Indian River lagoon system, Florida. Estuaries 4, 110-120.

Standora, E. A. \& Nelson, D. R. (1977). A telemetric study of the behavior of freeswimming Pacific angel sharks, Squatina californica. Bulletin of the Southern California Academy of Sciences 76, 193-201.

Turner, C. H. \& Strachan, A. R. (1969). The marine environment in the vicinity of the San Gabriel River mouth. California Fish and Game 55, 53-68. 